\title{
Plasma magnesium concentration in patients undergoing coronary artery bypass grafting
}

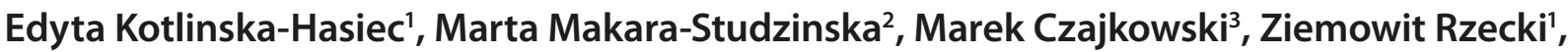 \\ Krzysztof Olszewski ${ }^{3}$, Adam Stadnik ${ }^{3}$, Jacek Pilat ${ }^{4}$, Beata Rybojad', Wojciech Dabrowski ${ }^{1}$ \\ ${ }^{1}$ Department of Anaesthesiology and Intensive Therapy Medical Universitty of Lublin, Poland \\ ${ }^{2}$ Department of Health Psychology Jagiellonian University - Collegium Medicum, Kraków, Poland \\ ${ }^{3}$ Department of Cardiac Surgery Medical University of Lublin, Poland \\ ${ }^{4}$ Department of General Surgery, Transplantology and Clinical Nutrition Medical University of Lublin, Poland
}

Plasma magnesium concentration in patients undergoing coronary artery bypass grafting Kotlinska-Hasiec E, Makara-Studzinska M, Czajkowski M, Rzecki Z, Olszewski K, Stadnik A, Pilat J, Rybojad B, Dabrowski W. Ann Agric Environ Med. 2017; 24(2): 181-184. doi: 10.5604/12321966.1232762

\begin{abstract}
Introduction. Magnesium (Mg) plays a crucial role in cell physiology and its deficiency may cause many disorders which often require intensive treatment. The aim of this study was to analyse some factors affecting preoperative plasma Mg concentration in patients undergoing coronary artery bypass grafting (CABG).

Materials and method. Adult patients scheduled for elective CABG with cardio-pulmonary bypass (CPB) under general anaesthesia were studied. Plasma Mg concentration was analysed before surgery in accordance with age, domicile, profession, tobacco smoking and preoperative $\mathrm{Mg}$ supplementation. Blood samples were obtained from the radial artery just before the administration of anaesthesia.

Results. 150 patients were studied. Mean preoperative plasma Mg concentration was $0.93 \pm 0.17 \mathrm{mmol} / \mathrm{L}$; mean concentration in patients - $1.02 \pm 0.16$; preoperative Mg supplementation was significantly higher than in patients without such supplementation. Moreover, intellectual workers supplemented Mg more frequently and had higher plasma Mg concentration than physical workers. Plasma Mg concentration decreases in elderly patients. Patients living in cities, on average, had the highest plasma Mg concentration. Smokers had significantly lower plasma Mg concentration than non-smokers.

Conclusions. 1. Preoperative magnesium supplementation increases its plasma concentration. 2. Intellectual workers frequently supplement magnesium. 3. Smoking cigarettes decreases plasma magnesium concentration.
\end{abstract}

\section{Key words}

magnesium, supplementation, age, profession, community education

\section{INTRODUCTION}

Magnesium (Mg) is an intracellular cation and plays a crucial role in many metabolic processes. Its deficiency leads to many life-threatening disorders, particularly of the heart and central nervous system $[1,2]$. The homeostasis of $\mathrm{Mg}$ depends on supplementation, accumulation and extraction with diuresis, stool and perspiration. Daily demand of $\mathrm{Mg}$ increases with age and ranges between 300-400 mg per day in adults [2]. Physiological plasma Mg concentration ranges from $0.8-1.2 \mathrm{mmol} / \mathrm{L}$, and even the smallest changes in its plasma level reflects in its intracellular level, leading to cellular dysfunctions $[1,3]$. Several pathologies, such as kidney diseases, diarrhoea, stress and neuroses, alcoholism and diabetes may reduce plasma $\mathrm{Mg}$ concentration. Moreover, its low concentration has been noted in patients treated with diuretics $[2,4,5]$.

Many pathologies are observed in patients undergoing cardiac surgery, and cardiac surgery with cardiopulmonary bypass (CBP) affects plasma $\mathrm{Mg}$ concentration. Perioperative stress, normovolemic haemodilution during $\mathrm{CBP}$ and raised loss with diuresis significantly reduce its plasma concentration [6-8]. Interestingly, the degree of plasma $\mathrm{Mg}$ concentration depends on its preoperative level $[8,9]$. The aim of the presented study is to analyse some factors

Adress for correspondence: Wojciech Dabrowski, Department of Anaesthesiology and Intensive Therapy Medical Universitty of Lublin, Poland

E-mail:w.dabrowski5@yahoo.com

Received: 8 April 2013; accepted: 7 October 2014; first published on January 2017 affecting preoperative plasma $\mathrm{Mg}$ concentration in patients undergoing coronary artery bypass grafting (CABG).

\section{MATERIALS AND METHOD}

This prospective study was conducted in the Cardiac Surgery Clinic of the Medical University in Lublin, Poland. The study design was approved by the Committee for Bioethics of the the Medical University and written informed consent was obtained from all patients. Patients scheduled for elective coronary artery bypass grafting surgery (CABG) with CBP due to stable angina were included.

All participants received the same premedication: one day before surgery - oral lorazepam (Lorafen, Polfa, Poland) at the dose of $2 \mathrm{mg}$, and one hour before the induction of anaesthesia - intramuscular midazolam (Sopodorm, Polfa, Poland) with morphine hydrochloride (Morphicum hydrochloricum, Polfa, Poland) at the doses $0.01 \mathrm{mg} / \mathrm{kg}$ body wt. and $0.1 \mathrm{mg} / \mathrm{kg}$ body wt., respectively. General anaesthesia was induced using fentanyl (Fentanyl, Polfa, Poland), midazolam and etomidate (Etomidate, Braun, Germany). Muscle relaxation was obtained with a single dose of pancuronium (Pavulon, Jelfa, Poland). For CBP, standard cannulations of the ascending aorta and inferior vena cava through the right atrium were performed. During CBP, circulation and ventilation were maintained with a heartlung machine (S III, Stöckert GmBH, Munich, Germany), and mean arterial pressure maintained between $45-105 \mathrm{mmHg}$. 
After traditional aortic clamping, myocardial viability was preserved with repeated antegrade hyperkalaemic warm blood cardioplegia. During mild hypothermic CBP, the mean arterial pressure, haematocrit and blood gas parameters, as well as the lactate, sodium and potassium levels were measured. Distal anastomoses were performed during cardioplegic arrest, whereas proximal anastomoses were performed following resumed perfusion and a side-biting clamp. In patients requiring inotropic support, dopamine or dobutamine infusions were used at doses dependent on the patient's haemodynamic status. The effect of heparin was reversed using an adequate dose of protamine sulphate (Protaminum sulphuricum, Biomed, Warsaw, Poland).

After surgery, patients were sent to the postoperative intensive care unit (PICU). All the patients were ventilated using synchronised intermittent mandatory ventilation (SIMV) with pressure support. Patients were extubated 8-12 hours after surgery.

Study protocol and patient distribution. Before anaesthesia, blood samples were collected from the radial artery for total $\mathrm{Mg}$ measurements. Plasma Mg concentration was analysed in accordance with age, domicile (participants living in a village, small city (population less than 20,000), mediumsize city (population from 20,000-100,000) and a big city (population higher than 100,000) [10], type of job (intellectual vs. physical), tobacco smoking (smokers vs. not smoking cigarettes) and preoperative $\mathrm{Mg}$ supplementation.

A spectrophotometric analysis was used to measure the plasma total $\mathrm{Mg}$ concentration. Blood samples were immediately centrifuged at 2,500 r/min, and the resulting plasma frozen at $-20^{\circ} \mathrm{C}$. Next, xylidine blue was added to each of the defrosted samples. The plasma total $\mathrm{Mg}$ concentrations were determined using spectrophotometry with ultraviolet light at a wavelength of $520 \mathrm{~nm}$ (Spectrophotometer SPECORD M40, Zeiss, Jena, Germany).

Statistics. Means and standard deviations (SD) were calculated for parametric data. Categorical variables were compared using the $\chi^{2}$ and Fisher exact tests, and the Yates correction was applied. The unpaired Student's t-test was used to analyse variables with normal distribution. Non-parametric data were statistically analysed using the Wilcoxon signed-rank test and the Kruskal-Wallis ANOVA test for initial detection of differences. $\mathrm{P}<0.05$ was considered to be statistically significant. The statistical analysis was determined by Statistica 9 software. The power of all statistical tests was determined by $G^{\star}$ Power software $(1-\beta)$.

\section{RESULTS}

150 adult patients (21 females; 129 males) aged $65 \pm 7$, undergoing elective CABG under general anaesthesia were studied. 43 lived in small villages, 33 lived in small cities, 44 in a medium-size city and 30 in a big city (Tab. 1). 61 participants worked intellectually and 89 physically (including agricultural work).

Mean value of plasma $\mathrm{Mg}$ concentration was $0.93 \pm 0.17 \mathrm{mmol} / \mathrm{L}$ in studied population. The highest plasma $\mathrm{Mg}$ concentration was noted in patients living in cities and the lowest in patients living in small villages (Fig. 1). In the studied population, $40 \%$ of the patients regularly
Table 1. Demographic data. medium city

\begin{tabular}{|c|c|c|c|c|c|}
\hline & $\begin{array}{c}\text { Studied } \\
\text { population }\end{array}$ & $\begin{array}{l}\text { Patients } \\
\text { living in } \\
\text { a small } \\
\text { village }\end{array}$ & $\begin{array}{l}\text { Patients } \\
\text { living in } \\
\text { a small } \\
\text { city }\end{array}$ & $\begin{array}{l}\text { Patients } \\
\text { living in } \\
\text { a middle } \\
\text { city }\end{array}$ & $\begin{array}{c}\text { Patients } \\
\text { living in } \\
\text { a large } \\
\text { city }\end{array}$ \\
\hline No. & 150 & 43 & 33 & 44 & 30 \\
\hline Age & $\begin{array}{c}65 \pm 7 \\
(42-80)\end{array}$ & $\begin{array}{c}66 \pm 6 \\
(52-72)\end{array}$ & $\begin{array}{c}67 \pm 6 \\
(53-80)\end{array}$ & $\begin{array}{c}65 \pm 7 \\
(51-78)\end{array}$ & $\begin{array}{c}64 \pm 8 \\
(42-75)\end{array}$ \\
\hline $\mathrm{BMI}$ & $26.45 \pm 3.9$ & $26.7 \pm 4.1$ & $26.3 \pm 3.5$ & $26.9 \pm 4.2$ & $25.5 \pm 3.5$ \\
\hline Female & 21 & 8 & 3 & 6 & 4 \\
\hline Male & 129 & 35 & 30 & 38 & 26 \\
\hline \multirow{2}{*}{$\begin{array}{l}\text { Kind } \\
\text { of } \\
\text { work }\end{array}$} & 89 & 30 & 21 & 22 & 16 \\
\hline & 61 & 13 & 12 & 22 & 14 \\
\hline Hypertension & $\begin{array}{c}129 \\
(86 \%)\end{array}$ & $\begin{array}{c}37 \\
(86 \%)\end{array}$ & $\begin{array}{c}36 \\
(78.79 \%)\end{array}$ & $\begin{array}{c}35 \\
(79.55 \%)\end{array}$ & $\begin{array}{c}21 \\
(70 \%)\end{array}$ \\
\hline $\begin{array}{l}\text { Smoking } \\
\text { cigarettes }\end{array}$ & $\begin{array}{c}73 \\
(48.67 \%)\end{array}$ & $\begin{array}{c}21 \\
(48.83 \%)\end{array}$ & $\begin{array}{c}19 \\
(57.57 \%)\end{array}$ & $\begin{array}{c}19 \\
(43.18 \%)\end{array}$ & $\begin{array}{c}14 \\
(46.67 \%)\end{array}$ \\
\hline Cigarettes per day & $17 \pm 8$ & $16 \pm 8$ & $17 \pm 8$ & $21 \pm 8$ & $14 \pm 6$ \\
\hline $\begin{array}{l}\text { History of } \\
\text { smoking }\end{array}$ & $\begin{array}{c}44 \\
(29.33 \%)\end{array}$ & $\begin{array}{c}17 \\
(39.53 \%)\end{array}$ & $\begin{array}{c}7 \\
\text { (21.21\%) }\end{array}$ & $\begin{array}{c}14 \\
(31.82 \%)\end{array}$ & $\begin{array}{c}6 \\
(30 \%)\end{array}$ \\
\hline
\end{tabular}

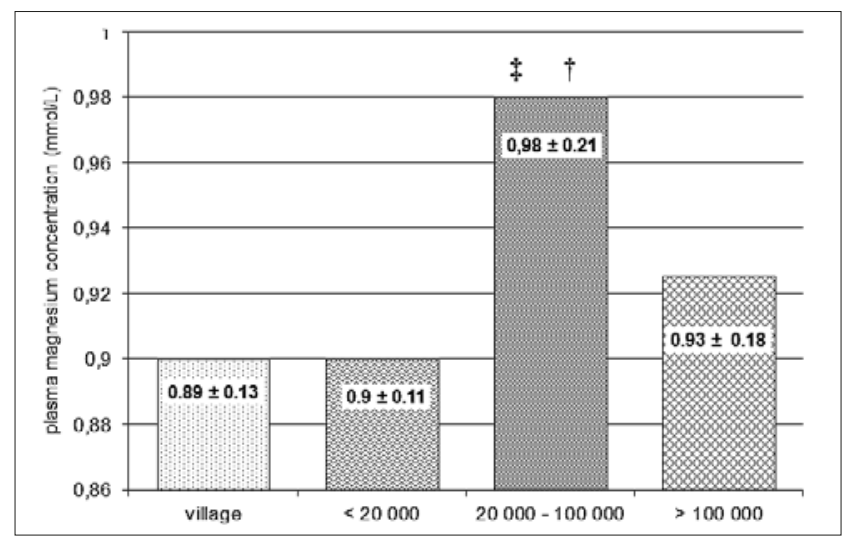

Figure 1. Mean plasma magnesium concentrations in patients living in village, small city (population less than 20,000), medium city (populati range 20,000-100,000) and big city (population more than 100,000)

supplemented $\mathrm{Mg}-25.58 \%$ of patients living in small villages, $33.33 \%$ of patients living in small cities, $52.27 \%$ of patients living in medium-size cities and $50 \%$ of patients living in big cities. Patients, who lived in medium sized cities supplemented $\mathrm{Mg}$ more often than those living in small villages $\left(\chi^{2}=6.51 ; \mathrm{p}=0.01\right.$ with $\left.\chi_{\text {Yates }}^{2}=5.43 ; \mathrm{p}=0.02\right)$ and more often than those living in small cities $\left(\chi^{2}=4.59 ; \mathrm{p}=0.03\right.$ with $\chi_{\text {Yates }}^{2}=3.59 ; \mathrm{p}=0.05$ ).

The frequency of smoking was similar in all groups (Fig. 2). Plasma Mg concentration was significantly lower in smokers and its mean value was $0.87 \pm 0.13 \mathrm{mmol} / \mathrm{L}$ (Fig. 3).

Mean plasma $\mathrm{Mg}$ concentration was $0.96 \pm 0.17 \mathrm{mmol} / \mathrm{L}$ in patients who had intellectual work, and was significantly higher $(\mathrm{p}<0.05)$ than in patients working physically, in whom the plasma $\mathrm{Mg}$ concentration was $0.9 \pm 0.16 \mathrm{mmol} / \mathrm{L}$. Magnesium level decreased in the elderly, and a rapid decline was observed in patients after the age of 65 (Fig. 4). 


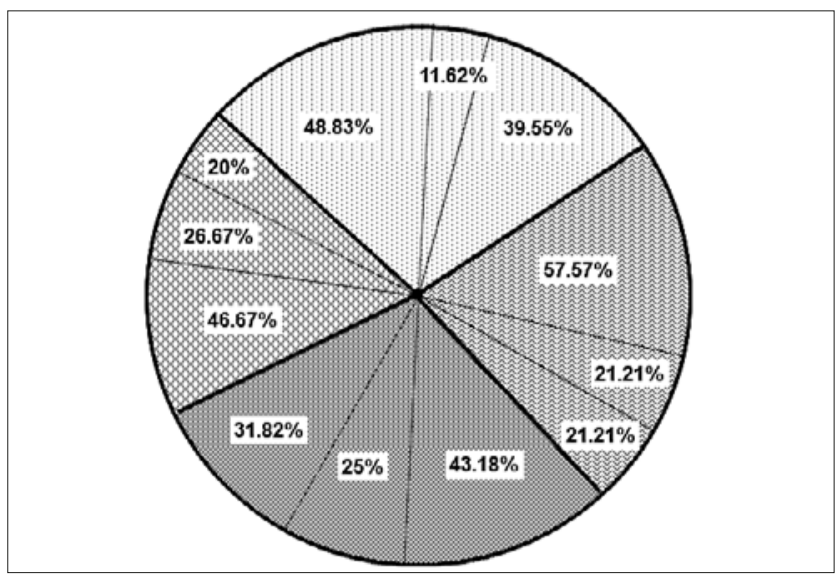

Figure 2. Percentage of smokers in accordance with domicile in participants living in a village: $48.83 \%$ smoked regularly before surgery, $11.62 \%$ never smoked and $39.55 \%$ smoked in the history. In patients living in a small city (population less than 20,000$), 57.57 \%$ smoked regularly before surgery, $21.21 \%$ never smoked and $21.21 \%$ smoked in the history. In patients living in a medium size city (population range $20,000-100,000$ ) $43.18 \%$ smoked regularly before surgery, $25 \%$ never smoked and $31.82 \%$ smoked in the history. In patients living in a big city (population more than 100,000$), 46.67 \%$ smoked regularly before surgery, $26.672 \%$ never smoked and $20 \%$ smoked in the history. Frequency of smoking was similar in all groups

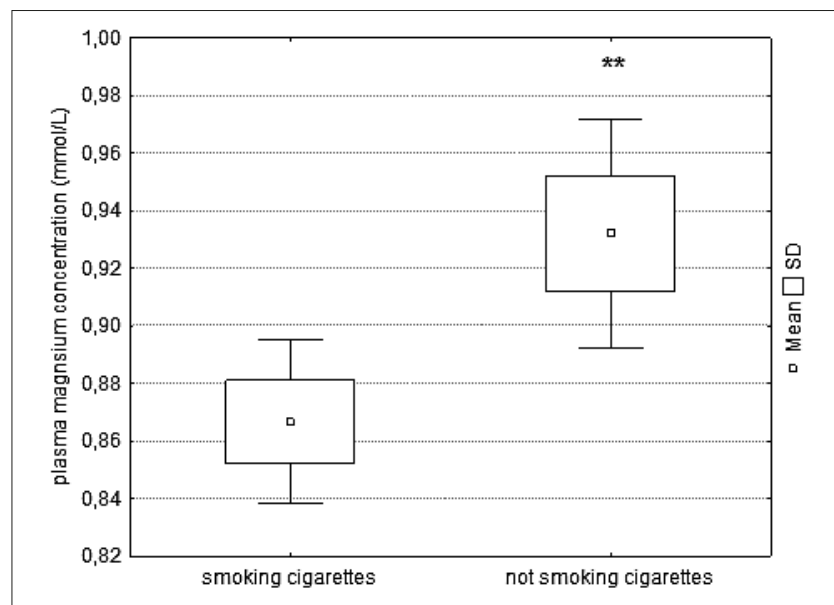

Figure 3. Changes in plasma magnesium concentration in patients who smoked cigarettes and patients, who did not smoke

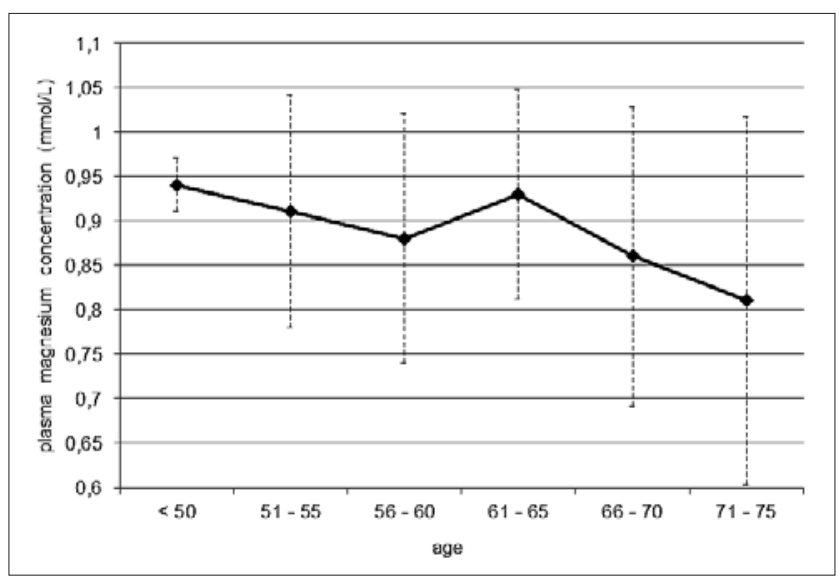

Figure 4. Changes in a mean plasma magnesium concentration according to age

\section{DISCUSSION}

The presented study demonstrates the profitable effect of regular Mg supplementation on its plasma concentration before cardiac surgery. Intellectual workers supplemented $\mathrm{Mg}$ more frequently than physical workers. Additionally, patients living in cities with an average population $(20,000-100,000)$ had the highest plasma Mg concentration. Interestingly, patients living in medium-size cities supplemented $\mathrm{Mg}$ more often than those who lived in small villages. Smoking cigarettes significantly decreases plasma $\mathrm{Mg}$ concentration. Plasma Mg concentration decreased in elderly patients.

There is a strong evidence that $\mathrm{Mg}$ plays a very important role in patients undergoing cardiac surgery. Perioperative hypomagnesaemia is associated with different forms of cardiac arrhythmias, particularly with atrial fibrillation $[8,11$, 12]. Magnesium stabilizes mitochondrial ion transport and calcium channel activity improving the cellular bioenergic status, which prevent abnormal pacemaker activity $[1,13,14]$. Intra-cardiac $\mathrm{Mg}$ reduces $\beta$-adrenergic stimulation [13], and interestingly, a 7\% reduction of intra-cardiac $\mathrm{Mg}$ increases 5 -fold the multivariate risk of postoperative atrial fibrillation in patients undergoing CABG [15]. For this reason, several authors have proposed perioperative infusion of $\mathrm{Mg}$ as a prophylactic treatment of post-operative cardiac arrhythmia $[8,11,12,14]$.

Magnesium also plays an important role in perioperative neuroprotection. It plays a crucial role in the regulation of calcium channel function and N-methyl-D-aspartate receptors (NMDA), and intracellular/mitochondrial metabolism [16]. Moreover, the blood-brain barrier (BBB) integrity strongly depends on brain $\mathrm{Mg}$ content, and increase in BBB permeability correlates with a decline in cerebral magnesium concentrations [17, 18]. Experimental and clinical studies have documented a neurprotective effect mediated by $\mathrm{Mg}$ in treatment of brain injury $[19,20]$. Nevertheless, a single use of $\mathrm{Mg}$ in post-traumatic neuroprotective treatment has been strongly controverted in recent years, and several authors have strongly suggested supporting other pharmacologic treatments by Mg infusion in patients after traumatic brain injury [19].

Plasma Mg concentration affects perioperative adrenergic response. An intraoperative infusion of magnesium sulphate significantly reduces the adrenergic response for surgical stress mediated by plasma epinephrine and norepinephrine concentrations $[9,21]$. Moreover, $\mathrm{Mg}$ attenuates the haemodynamic response on intubation in hypertensive patients [22]. Importantly, the majority of studied patients were treated for hypertension.

Cardiac surgery with CBP contributes to low plasma $\mathrm{Mg}$ concentrations and the degree of this disorders strongly depends on the preoperative plasma $\mathrm{Mg}$ concentration [6, 8 , 9]. Perioperative adrenergic reaction, increase in $\mathrm{Mg}$ depletion with urine, inadequate $\mathrm{Mg}$ supplementation and perioperative treatment may lead to hypomagnesaemia. However, intraoperative blood dilution during CBP is the most important factor contributing to perioperative hypomagnesaemia [23]. Several authors have shown a $17 \%$ decrease in plasma $\mathrm{Mg}$ concentration following normovolemic haemodilution $[24,25]$. Importantly, the preoperative $\mathrm{Mg}$ supplementation significantly improve its plasma concentration, reduces perioperative Mg disorders, reduces surgically-related adrenergic response, and improves 
the post-operative outcome $[8,9]$. Unfortunately, the majority of studied patients did not supplement $\mathrm{Mg}$ pre-operatively and $86 \%$ of them were treated for hypertension.

Finally, the presented analysis shows some factors affecting pre-operative plasma $\mathrm{Mg}$ concentration in patients undergoing elective CABG with CBP. Preoperative magnesium supplementation is most important because it significantly increases its preoperative plasma concentration. Interestingly, intellectual workers frequently supplemented magnesium. Smoking cigarettes decreased plasma magnesium concentration. The highest plasma $\mathrm{Mg}$ concentration was noted in patients living in cities with an average population (20,000-100,000) and the lowest in patients living in small villages.

\section{REFERENCES}

1. Pasternak K, Kocot J, Horecka A. Biochemistry of magnesium. J Elem 2010; 15(3): 601-616.

2. Whang R, Hampton EM, Whang DD. Magnesium homeostasis and clinical disorders of magnesium deficiency. Ann Pharmacother 1994; 28(2): 220-226.

3. Haigney MC, Silver B, Tanglao E, Silverman HS, Hill JD, Shapiro E et al. Noninvasive measurement of tissue magnesium and correlation with cardiac levels. Circulation 1995; 92(8): 2190-2197.

4. Pham PC, Pham PM, Pham PA, Pham SV, Pham HV, Miller JM et al. Lower serum magnesium levels are associated with more rapid decline of renal function in patients with diabetes mellitus type 2. Clin Nephrol 2005; 63(6): 429-436.

5. Weglicki W, Quamme G, Tucker K, Haigney M, Resnick L. Potassium, magnesium, and electrolyte imbalance and complications in disease management. Clin Exp Hypertens 2005; 27(1): 95-112.

6. Pasternak K, Dabrowski W, Wrońska J, Rzecki Z, Biernacka J, Jurko $C$ et al. Changes of blood magnesium concentration in patients undergoing surgical myocardial revascularisation. Magnes Res 2006; 19(2): 107-112.

7. Polderman KH, Girbes AR. Severe electrolyte disorders following cardiac surgery: a prospective controlled observational study. Crit Care 2004; 8(6): R459-R466.

8. Dabrowski W, Rzecki Z, Sztanke M, Visconti J, Wacinski P, Pasternak $\mathrm{K}$. The efficiency of magnesium supplementation in patients undergoing cardiopulmonary bypass: changes in serum magnesium concentrations and atrial fibrillation episodes. Magnes Res 2008; 21(1): 205-217.

9. Pasternak K, Dabrowski W, Dobija J, Wrońska J, Rzecki Z, Biernacka J. The effect of preoperative magnesium supplementation on blood catecholamine concentrations in patients undergoing CABG. Magnes Res 2006; 19(2): 113-122.
10. Runge A. Metodologiczne problemy badania miast średnich w Polsce. Prace geograficzne zeszyt 129. IGiGP UJ Kraków 2012; 83-101.

11. Khan AM, Lubitz SA, Sullivan LM, Sun JX, Levy D, Vasan RS et al. Low serum magnesium and the development of atrial fibrillation in the community: the Framingham Heart Study. Circulation 2013; 127(1): 33-38.

12. Gu WJ, Wu ZJ, Wang PF, Aung LH, Yin RX. Intravenous magnesium prevents atrial fibrillation after coronary artery bypass grafting: a metaanalysis of 7 double-blind, placebo-controlled, randomized clinical trials. Trials 2012; 13: 41

13. Watanabe J, Nakayma S, Matsubara T, Hotta N. Regulation of intracellular free $\mathrm{Mg}+2$ concentration in isolated rat hearts via $\beta$-adrenergic and muscarinic receptors. J Mol Cell Cardiol 1998; 30(11): 2307-18.

14. Chakraborti S, Chakraborti T, Mandal M, Mandal A, Das S, Ghosh $\mathrm{S}$. Protective role of magnesium in cardiovascular diseases: a review. Mol Cell Biochem 2002; 238(1-2): 163-79.

15. Abdel-Massih TE, Sarkis A, Sleilaty G, El Rassi I, Chamandi C, Karam $\mathrm{N}$ et al. Myocardial extraction of intracellular magnesium and atrial fibrillation after coronary surgery. Int J Cardiol 2012; 160(2): 114-118.

16. Furukawa Y, Kasai N, Torimitsu K. Effect of $\mathrm{Mg}^{+2}$ on neuronal activity of rat cortical and hippocampal neurons in vitro. Magnes Res 2009; 22(3): 174s-81s.

17. Yorulmaz H, Seker FB, Demir G, Yalçın IE, Oztaș B. The effects of zinc treatment on the blood-brain barrier permeability and brain element levels during convulsions. Biol Trace Elem Res. 2013; 151(3): 256-262.

18. Nimmo AJ, Cernak I, Heath DL, Hu X, Bennett CJ, Vink R. Neurogenic inflammation is associated with development of edema and functional deficits following traumatic brain injury in rats. Neuropeptides 2004; 38(1): 40-47.

19. Sen AP, Gulati A. Use of magnesium in traumatic brain injury. Neurotherapeutics 2010; 7(1): 91-99.

20. Fromm L, Heath DL, Vink R, Nimmo AJ. Magnesium attenuates posttraumatic depression/anxiety following diffuse traumatic brain injury in rats. J Am Coll Nutr 2004; 23(5): 529S-533S.

21. Pasternak K, Dabrowski W, Wyciszczok T, Korycińska A, Dobija J, Biernacka $J$ et al. The relationship between magnesium, epinephrine and norepinephrine blood concentrations during CABG with normovolemic hemodilution. Magnes Res 2005; 18(4): 245-252.

22. Panda NB, Bharti N, Prasad S. Minimal effective dose of magnesium sulfate for attenuation of intubation response in hypertensive patients. J Clin Anesth 2013; 25(2): 92-97.

23. Inoue S, Akazawa S, Nakaigawa Y, Shimizu R, Seo N. Changes in plasma total and ionized magnesium concentrations and factors affecting magnesium concentrations during cardiac surgery. J Anesth 2004; 18(3): 216-219.

24. Ichikawa S. Magnesium and calcium changes in serum and atrial muscle caused by open heart surgery and the effect of perioperative oral magnesium administration. Jpn J Thorac Cardiovasc Surg 1998; 46(3): 287-29.

25. Satur CM, Anderson JR, Jennings A, Newton K, Martin PG, Nair U et al. Magnesium flux caused by coronary artery bypass operation: three patterns of deficiency. Ann Thorac Surg 1994; 58(6): 1674-1678. 